ISSN 1982-8713

\title{
A Espiritualidade Suméria Como Agente do Pluralismo Religioso Mesopotâmico
}

\author{
The Sumerian Spirituality as an Agent of Mesopotamian Religious \\ Pluralism
}

\author{
Luana de Almeida Telles ${ }^{1}$ \\ Túlio Fernandes Brum de Toledo
}

\begin{abstract}
${ }^{1}$ Mestranda do PPCIR - Programa de pós-graduação em Ciência da Religião da Universidade Federal de Juiz de Fora (UFJF) com orientação do Prof. Dr. Clodomir Barros de Andrade. Bacharel em Ciência da Religião pela UFJF membro do grupo de pesquisa RENATURA (espiritualidades e natureza - UFJF). Apoio CAPES. E-mail: lulu telles@hotmail.com.

${ }^{2}$ Mestrando do PPCIR - Programa de pós-graduação em Ciência da Religião da Universidade Federal de Juiz de Fora (UFJF) com orientação da Profa. Dra. Maria Cecília dos Santos Ribeiro Simões. Bacharel e Licenciado em Ciência da Religião pela UFJF, membro do grupo de pesquisa RENATURA (espiritualidades e natureza - UFJF). Apoio CAPES. E-mail: tuliotoledo@hotmail.com.
\end{abstract}

Recebido em 03 de fevereiro de 2020; Aceito em 03 de junho de 2020

\section{Resumo}

O presente artigo busca apresentar e esclarecer questões relacionadas ao contexto religioso da Suméria. A diversidade de povos no território mesopotâmico e suas distintas representações aparecem como importantes modelos de estruturação civilizacional e religiosa do Oriente Próximo. Para entender tal cenário, foi necessário, primeiramente, um estudo do contexto histórico-religioso-político da região do Sul da Mesopotâmia. Ao analisar esse contexto presente na idade antiga, reconhece-se a presença de um intenso pluralismo religioso e suas variadas manifestações no cotidiano dessas culturas, além de um intenso sincretismo, em que, a base desse sistema religioso ancorava-se nos ideais sumérios. A importância da simbologia dos templos e das divindades padroeiras sustentava o imaginário tanto dos indivíduos, como do funcionamento daquelas cidades.

Palavras-chave: Mesopotâmia; Suméria; Religião; Cosmogonia; Zigurate.

\section{Abstract}

This article seeks to present and clarify issues related to the religious context from Sumeria. The diversity of peoples in the mesopotamian territory and its distinct representations appear as important models of structuring of the civilisation and religion in the Near East. To understand such scenario, it was necessary, first, a study of the historical-religious-political context in the region of southern Mesopotamia. To 
analyze this context presented in old age, it's necessary to recognize the presence of an intense religious pluralism and its various manifestations in the daily life of these cultures, in addition to an intense syncretism, in which the basis of this religious system was founded in the ideals of the sumerians. The importance of the symbolism of the temples and the highlighted deities maintains the imaginary of both individuals, such as the functioning of those cities.

Keywords: Mesopotamia; Sumeria; Religion; Cosmogony; Ziggurat.

\section{Introdução}

A Mesopotâmia - palavra de origem grega que significa terra entre rios - estava localizada no que era chamado Crescente Fértil, disposta ao longo da margem dos rios Eufrates e Tigre. O território mesopotâmico estava dividido em três regiões - entre três culturas: os assírios residentes ao norte, os acádios no centro - ambos semitas - e os sumérios ao sul. Dentre o quarto e o terceiro milênio AEC começaram a surgir núcleos urbanos ao longo da Baixa Mesopotâmia, e depois cidades como Uruk, Ur e Eridu que no decorrer desse período passaram a ser dominadas por dinastias sumerianas. Com a ascensão do império semítico de Akkad, o rei Sargão I conseguiu unificar toda a Mesopotâmia - foi um breve reinado, pois logo começaram as invasões dos gutis e dos elamitas - o que proporcionou o surgimento do império Neo-Sumério, conhecido como III (terceira) Dinastia de Ur. Posteriormente, foram dominados pelos amoritas no segundo milênio AEC estabelecendo assim, a fase dos babilônios e o fim da supremacia suméria na região. Podemos pensar na mesopotâmia - até a época de Alexandre, o Grande - como sendo, um incitante mecanismo de trocas culturais que, através do comércio, das tecnologias e até mesmo das dominações, produziu diversas interpretações, adaptações e formas nas multifacetadas expressões identitárias características de cada civilização, passíveis de transformações e combinações culturais.

A Suméria está localizada onde hoje seriam o Iraque e o Kuwait, acredita-se que foi a primeira civilização a se desenvolver nessa região por volta de 4.000 AEC. É preciso então, ter em mente que, o processo de formação das culturas mesopotâmias, não segue uma cronologia linear, ele surge simultaneamente em diferentes regiões, em 
diferentes velocidades e com múltiplos resultados. Os assentamentos de Hassuna e Samarra no sexto milênio AEC, o de Tell Halaf no quinto milênio AEC e mais tarde, o período de El Obeid na segunda metade do quinto milênio, já demonstravam características próprias, que se tornavam cada vez mais complexas com o passar do tempo. Nestes povos antigos já existiam indícios de representações divinas, como por exemplo, da deusa-mãe. Considera-se hoje que, foi diante desta simbiose heterogênea de civilizações presentes na mesopotâmia, que os sumérios desenvolveram-se. Originalmente, acreditava-se que os sumérios eram nômades peregrinando desde o Planalto do Irã e dos Montes Zagros (Ásia Central), até sua chegada à mesopotâmia e seu encontro com os outros povos que ali já estavam.

Kriwaczek (2018, p. 37) diz: "Com a cidade vieram o Estado centralizado, a hierarquia de classes sociais, a divisão do trabalho, a religião organizada (...)". Diz ainda que, para essa civilização urbana que emergiu o momento da transição de um nomadismo para a agricultura foi marcado pelo surgimento de uma nova religião, e, "os primórdios dessa ideologia encontram-se em Eridu" (KRIWACZEK, 2018, p. 37). Os sumérios eram politeístas, isto é, sua religião comportava diversos deuses. Estes possuíam diversificados campos de atuação: existia a deusa do amor, da guerra, da agricultura. O mundo dos deuses era organizado como o dos homens: a partir de uma hierarquia familiar ou estatal, que poderia ser alterada de acordo com a importância das cidades, e estes eram dotados de sentimentos humanos. Gaarder (2000, p. 20) diz que, era comum nas religiões de seio indo-europeu - ou seja, indianas, gregas, romanas e germânicas - que o deus do céu fosse tido como o maior de todos, uma espécie de deus supremo, pois ele estava associado com a abóbada celeste; frequentemente, ele formava um casal com a divindade feminina que representava a terra, estruturando assim o Pai Céu que fecunda a Mãe Terra, essencial para uma cultura sedentária agrária - similarmente, ocorreu com os sumérios, onde o casal é representado por An e Ki.

Gaarder (2000, p. 36) também apresenta a ideia que este é um caso de religião nacional, onde existe uma mitologia concisa, um sacerdócio permanente encarregado 
dos deveres rituais nos templos, um culto sacrificial e uma monarquia sacra - onde os deuses escolhiam o líder da nação. A história da mesopotâmia apresenta-se como uma sucessão de dinastias, instaladas em diferentes cidades e que, alternavam sua hegemonia sobre aquele território. A civilização, isto é, a sociedade era padronizada seguindo o plano criado pelos deuses através de regras destinadas a organizar as atividades dos governantes e do comportamento humano. Essas regras eram conhecidas como me. Os me então, definiam os aspectos do governo, religião, guerra, paz, sexualidade, profissões, código de conduta e noções de certo e errado. A implementação destes na humanidade seria supervisionada pelos deuses.

\section{O Contexto Político e Histórico}

De certa forma, apesar das diferentes invasões, pode-se dizer que existe uma estrutura religiosa mesopotâmica, pois existiam regiões em que os componentes locais eram mais proeminentes, uma espécie de base em comum que teria sua origem na religião suméria. Durante os períodos iniciais dos agrupamentos que surgiram na Revolução Urbana, cada povoamento adorava uma divindade local principal que assegurava a prosperidade da sua comunidade, sendo que, existiam também cultos de outros deuses menores. A popularidade e grau de importância de tal padroeiro divino crescia em paralelo com o desenvolvimento de sua cidade. Beaulieu (2007, p. 167) afirma que, muitos conceitos e costumes foram mantidos do início ao fim, como por exemplo, a concepção que as divindades eram os governantes reais das cidades ou que, os templos eram a residência desses seres. Muitos daqueles cultos e festivais ocorreram "do ano de 2000 AEC da mesma forma como ocorriam em 500 AEC", embora, com o desenrolar do tempo, novos deuses eram agregados ao conjunto e sua estrutura hierárquica moldava-se de acordo.

O panteão mantinha suas características essenciais, mesmo com as mudanças políticas entre reis ou povos de influência, que ora refletiam particularmente na adição de novos deuses. 
NEARCD: Revista Eletrônica de Antiguidade 2020, Volume XII, Número I - ISSN 19882-8713

Núcleo de Estudas da Antiguidade -NEA

Universidade do Estada do Rio de Janeiro

ISSN 1982-8713

\begin{abstract}
O panteão sumério, em particular, não desapareceu ao mesmo tempo que a independência política das cidades. Muito ao contrário, foi assimilado com facilidade tanto maior, na medida em que integrava a herança cultural a que eram sensíveis os soberanos de Akkad, e em que o politeísmo tolerava, havia muito, um vasto sincretismo. Numerosas divindades semíticas encontraram suas correspondentes sumérias, e algumas figuras mais originais, tanto sumérias como semitas, impuseram-se à sensibilidade religiosa de ambas as populações. (...) No máximo, observa-se sob seus reinados, um aumento da popularidade de certas figuras, como Shamash e, sobretudo Ishtar, mas, no conjunto, a simbiose mesopotâmica já se consumara no campo do pensamento religioso. (GARELLI, 1982, p. 92)
\end{abstract}

Existiam ocasiões em que a interferência política na esfera religiosa tornava-se mais acentuada, Beaulieu (2007, p. 165) destaca duas: 1) Os primeiros soberanos reuniam tanto o poder "secular, político" quanto o religioso. A situação, contudo, foi se alterando durante as primeiras dinastias dos períodos Sargônico e Neo-Sumério, onde se concretizou um cenário mais secular para o Estado; e 2) 0 entrelaçamento da proeminência política com o poder da divindade patrona de cada cidade buscava explicar a emergência de uma cidade sobre as outras.

Podemos observar três momentos destacados nessa civilização: o surgimento das cidades-templo - o templo controla a estrutura da cidade -, o crescimento das cidades-estados - com governo próprio e autônomo - e o desenvolvimento dos estados nacionais - que propagavam a unidade étnica, cultural e religiosa. A primeira cidade propriamente dita na Suméria foi Eridu, porém a primeira civilização que se tornou urbana foi Uruk, embora ambas não passassem de meros assentamentos por volta do quarto milênio AEC. Quinhentos anos mais tarde Uruk tornou-se modelo para as outras cidades mesopotâmias se urbanizarem, seu padroeiro era o Deus $\mathrm{Na}$. No inicio do terceiro milênio AEC, o deus Enlil ganhou extrema importância no panteão sumério e sua cidade, Nippur, assumiu o papel de centro cultural e religioso da suméria. Já no meio do terceiro milênio $A E C$, encontrou-se um favorecimento ao deus Enki de Eridu, mostrando como era dinâmica a alternância de poder entre os deuses e automaticamente entre as cidades que os mesmos representavam. No período Sargônico, devido à influência da deusa Ishtar de Akkad - correspondente acádia de 
Inanna - o templo e a cidade de Uruk também atingiram um status privilegiado. Já o período Neo-Sumério foi marcado por uma época de influência da cidade de Ur - sob a "regência" da deusa Nanna, a lua - sobre a Mesopotâmia.

Os sumérios não possuíam uma uniformidade política, ou seja, não existia um estado centralizado. Eles se organizavam em Cidades-Estados com governos autônomos, onde cada uma possuía seu próprio soberano. A primeira vez que a Suméria foi unificada sobre um mesmo dirigente foi durante o período pré-dinástico, com Urukagina. Essa falta de coesão política forte sujeitou não só os sumérios, mas o território da Mesopotâmia como um todo, a diversas invasões e impérios diferentes. 


\section{ب}

包[ NEARCO

Revista Eletrônica de
Antiguidade e Medievo
NEARCD: Revista Eletrônica de Antiguidade 2020, Volume XII, Número I - ISSN 1982-8713 Núcleo de Estudas da Antiguidade -NEA

Universidade da Estada do Rio de Janeiro

ISSN 1982-8713

Figura 1: Representação da deusa de Akkad, Ishtar, identificada também como a deusa Inanna.

\section{Fonte:}

https://research.britishmuseum.org/research/collection online/collection object detai

Is.aspx?objectld=1355376\&partld=1

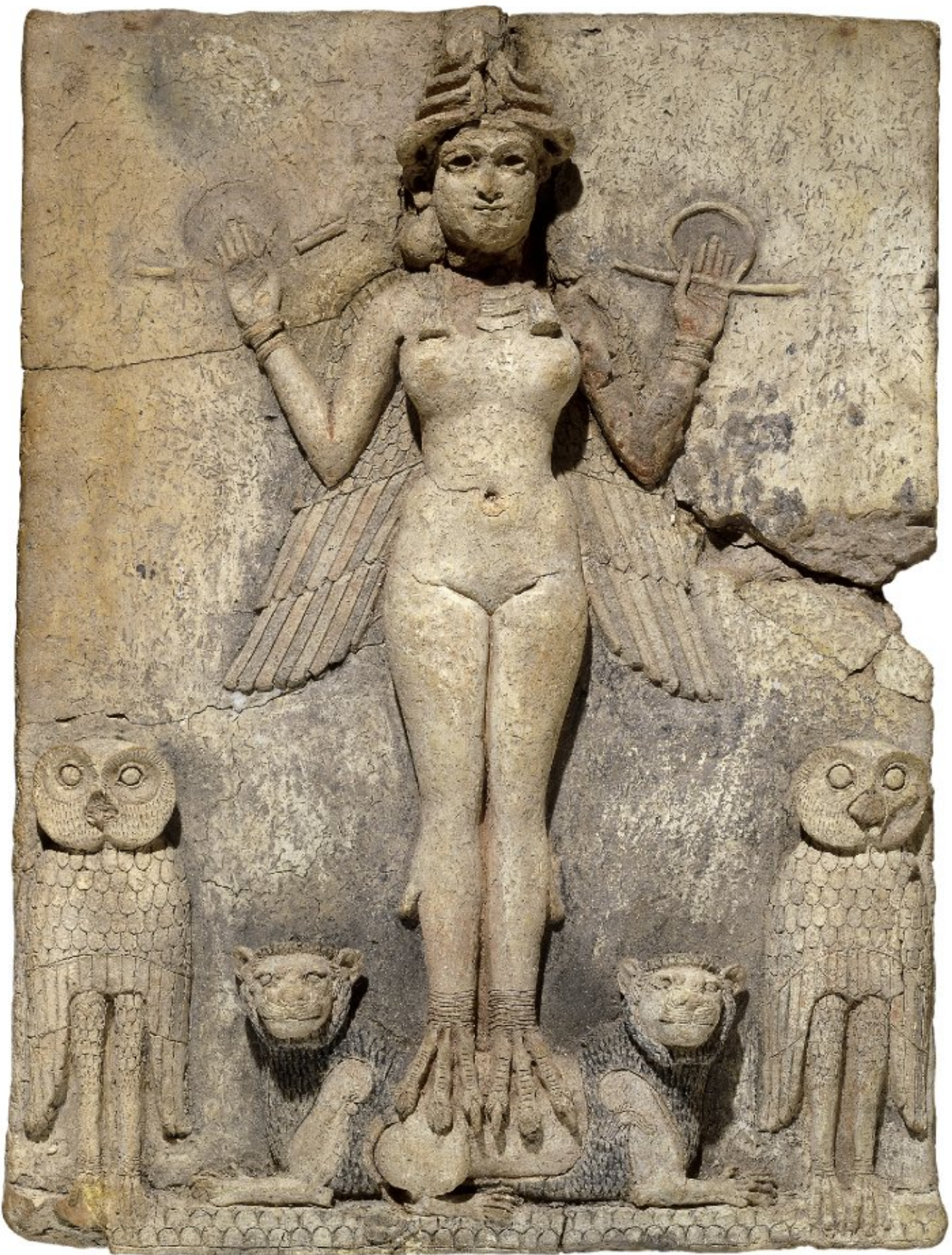


ISSN 1982-8713

Adiante, observa-se uma tabela ${ }^{75} \mathrm{com}$ a relação de domínio sobre o território que os sumérios ocupavam.

Tabela 1: Cronologia de influência sobre o Sul da Mesopotâmia AEC

\begin{tabular}{rrr}
\hline Assentamentos na região da & & \\
Suméria & 5000 & \\
Período Proto-Histórico & 3500 & Aparecimento da Escrita \\
Suméria Pré-Dinástica & $2900-$ & \\
& 2370 & \\
& $2370-$ & \\
& 2230 & \\
& $2230-$ & Império de Akkad \\
& 2111 & \\
& $2111-$ & \\
& 2003 & \\
& $2003-$ & Invasão dos Elamio dos Gutis \\
& 1792 & Amoritas \\
\hline
\end{tabular}

Com relação aos chefes estatais, durante a Suméria pré-dinástica, duas personalidades se destacaram entre os soberanos: Gilgamesh e Urukagina. Relatos apontam que, Gilgamesh reinou na cidade de Uruk por volta de $2.600 \mathrm{AEC}$, sendo o quinto monarca pós-dilúvio. A admirável epopéia de Gilgamesh retrata as façanhas do monarca divinizado, revelando o processo de separação do homem da natureza, e, além disso, apresenta um mito de fundação da inevitabilidade da morte e do limite da realeza no mundo humano. Segue abaixo uma breve síntese.

Gilgamesh, conta a história, exercia sua liderança de forma abrupta e de certa forma tirânica, e também, foi um grande construtor de baluartes e muralhas, por estes e outros motivos, era visto como um soberano impregnado pela luxúria. Entre os

75 Fontes: GARELLI, Paul. O Oriente Próximo Asiático. São Paulo: EDUSP, 1982; KRIWACZEK, Paul. Babilônia: a Mesopotâmia e o nascimento da civilização. Rio de Janeiro: Zahar, 2018. 
habitantes da cidade eram inúmeras as queixas sobre o comportamento de seu líder e, após incessantes orações e lamentos do povo, o deus An, pede para Nammu, dar vida a uma criatura de extrema grandeza, que pudesse enfrentar Gilgamesh, deixando assim, a cidade de Uruk em paz. A deusa então, atendendo ao pedido mergulhou suas mãos na água, pegou um pedaço de barro e o deixou cair na selva, criando assim o nobre Enkidu. Enkidu inicia assim, sua destinada batalha contra Gilgamesh, que depois de algumas demonstrações de poder de ambos os lados, chegaram à conclusão da equiparidade de suas forças e a luta se interrompeu. E deste encontro nasceu uma plena amizade, Enkidu e Gilgamesh tornaram-se fabulosos companheiros de aventuras.

A deusa Inanna encantada com as façanhas de Gilgamesh, o propõe em casamento, mas ele recusa sua oferta, colocando-se a mercê de toda fúria da deusa, que pede para o Deus An enviar um touro celeste para destruí-lo. A batalha da dupla, Gilgamesh e Enkidu contra a fera do céu, devastou Uruk, tendo como consequência sete anos de seca. Os deuses ficaram insatisfeitos com a derrota do touro, e resolveram retirar a vida doada a Enkidu. Diante de um extremo e doloroso luto pela perda do amigo-irmão, Gilgamesh muda o foco de sua busca, que antes, movida pela perpetuação do heroísmo, passa a ser direcionada para uma procura incansável pela imortalidade. Então, imerso em sua nova jornada, corre em busca do homem que havia adquirido a vida eterna: o escolhido a sobreviver ao dilúvio, chamado Ziusudra em sumério, Utnapishtim em acádio. Ziusudra revelou-o a existência de uma planta que habitava o fundo do mar cósmico, que era capaz de conceder a vida eterna para quem a consumisse. Gilgamesh depois de capturar a planta extraordinária - retornando para casa - parou para descansar e acabou adormecendo, em estado de sono, uma cobra surge e come a planta mística - era dito, que foram os deuses que enviaram a cobra para manter o segredo da imortalidade entre eles. Como consequência, desse dia em diante a serpente obteve a capacidade de se renovar, podendo retirar a própria pele e recuperar a juventude, assim, encerra-se a epopéia. 
NEARCD: Revista Eletrônica de Antiguidade 2020, Volume XII, Número I - ISSN 19882-8713

Núcleo de Estudas da Antiguidade -NEA

Universidade do Estada do Rio de Janeiro

ISSN 1982-8713

Outra liderança que marcou história foi Urukagina (reinado c. 2380-2360 AEC), período conhecido por uma tensão entre a autoridade do rei em ascensão e a comunidade. De acordo com Lerner $(1987$, p. 57), seu reinado foi marcado também por variadas reformas sobre os impostos e tarifas, ele retirou o poder de oficiais corruptos e governou os templos em nome de deus. Acusou seu antecessor de se apropriar de propriedades dos templos; afirmava que, sobre o governo de Lugalanda, os sacerdotes - ensi - tinham começado a tomar conta de terras privadas, e também que, invadiam e apropriavam-se de plantações. Havia o abuso de poder dos sacerdotes através da cobrança de taxas extras para funerais e rituais religiosos. Urukagina subiu ao poder quando, dizendo agir em nome dos pastores e fazendeiros, destronou Lugalanda, pronunciando que este era favorecido pelo sacerdócio. No segundo ano de seu governo declara-se rei - lugal.

Durante o terceiro milênio antes da era comum, um grupo de semitas instalouse na babilônia, em Akkad. A partir de 2300 AEC dominaram a suméria quando, Sargão (reinado c. 2270-2215 AEC) formou o primeiro Império semita na Mesopotâmia. Derrotou o rei de Kish e fundou a cidade de Akkad - que se tornou a capital de seu império -, conquistou também as regiões próximas. Por conseguinte, pela primeira vez, observou-se uma unificação política do território mesopotâmico, sob a dinastia de Sargão I e também, uma verdadeira expansão imperialista. O Império de Akkad estendia-se do território do Elam até o mar Mediterrâneo, da Anatólia à península Arábica, incluindo toda a Mesopotâmia. Como unificador daquela enorme teia de cidades, Sargão entra para história como o primeiro verdadeiro Rei mesopotâmico, e não um simples chefe local. Foram tempos de grandes realizações, um período em que se iniciam processos de transliteração de diversas histórias sumérias para a linguagem semítica, chamada acádica. Alguns de seus deuses foram identificados com os dos sumérios, tais como: An torna-se Anu, Enki em Ea e, Nanna e Utu eram Sin e Shamash. A principal deusa de Akkad foi Ishtar, identificada como a deusa Inanna. Não se tratava apenas de uma troca de nomes divinos, mas sim, cada ressignificação levava consigo 
NEARCD: Revista Eletrônica de Antiguidade 2020, Volume XII, Número I - ISSN 19882-8713

Núcleo de Estudas da Antiguidade -NEA

Universidade do Estada do Rio de Janeiro

ISSN 1982-8713

grandes influências culturais e locais de acordo com os distintos lugares e povos envolvidos nos processos. Um ponto que merece atenção é a história da infância de Sargão que se assemelha bastante com a de Moisés. Sargão nasceu em uma pequena aldeia, seu pai era desconhecido e sua mãe sacerdotisa, sem possibilidades de continuar com a criança sozinha, sua mãe o coloca dentro de um cesto lançando-o nas correntes do rio Eufrates. Foi encontrado e resgatado por um horticultor que o criou e o ensinou sua profissão.

Com a invasão dos gutis - povo que habitava os montes Zagros - o império de Sargão termina. Posteriormente, o soberano Ur-Nammu (reinado c. 2112-2095 AEC) da terceira dinastia de Ur consegue expulsar os invasores gutis desse território, resultando no ressurgimento da força e influência dos sumérios na Mesopotâmia, período que ficou conhecido como Império Neo-Sumério ou III Dinastia de Ur (Ur III). Mais tarde, ocorre à invasão amorita no período de Ibbi-Sin (reinado c. 2030-2022 AEC), destruindo assim todo o império Neo-Sumério - o rei foi capturado e morto. O domínio amorita ficou conhecido como Império Babilônico.

O modelo religioso que se difundiu na região mesopotâmica e depois marcou presença na costa palestina do mediterrâneo e ao norte, na Anatólia hitita, era o modelo sumério. No entanto, cada cultura o reelaborou de forma própria e original. Nessa perspectiva, as civilizações posteriores na região mesopotâmica foram caracterizadas por uma identidade e unidade cultural 'básica', uma espécie de substrato que permitia que seus sistemas religiosos fossem tratados de maneira homogênea. Se um dia for possível demonstrar, como às vezes se suspeita que, o sumério não era uma cultura etnicamente diversa da dos acádios, babilônicos e assírios, mas apenas uma língua especial de caráter religioso, essa unidade seria ainda mais justificada. As diferenças são, provavelmente, fruto do tempo e das adaptações exigidas pelas mudanças de suas necessidades. (SCARPI, 2004, p. 27).

\section{O Contexto Social e Religioso}

Há cinco mil anos se desenvolvia uma civilização sedentária, agrícola e pastoreia que, estava se urbanizando rapidamente, demandando trabalho e organização - social e técnica - tornando assim, possível administrar e desfrutar da natureza e do seu território. E, para que essas exigências fossem cumpridas, seria necessária uma 
NEARCD: Revista Eletrônica de Antiguidade 2020, Volume XII, Número I - ISSN 19882-8713

Núcleo de Estudas da Antiguidade -NEA

Universidade do Estada do Rio de Janeiro

ISSN 1982-8713

progressão intelectual daquela sociedade e também o desenvolvimento de uma moral para harmonizar e direcionar esse sistema. Para essa estrutura funcionar, era preciso que os indivíduos da comunidade trabalhassem em conjunto - ou seja, o trabalho de um, influenciava diretamente no do próximo - o coletivo dependia do individual. Esta organização possibilitou a construção de obras hidráulicas e tornou possível o comércio com outros povos; "depois surgiram os soldados para proteger os comboios, escribas para registrar os negócios e toda uma gama de funcionários do Estado para conciliar eventuais conflitos de interesses" (PINSKY, 2018, p. 65). Aparecem também funcionários religiosos e templos. A linguagem e a cultura suméria dominavam a região, de forma que, pode-se dizer que a base da religião mesopotâmia é a dos sumérios.

Pinsky (2018, p. 71) coloca que, provavelmente, foram nos templos em que, pela primeira vez, observou-se a especialização das tarefas e da mão-de-obra. A força de trabalho do templo e a produção eram organizadas pelos sacerdotes.

\begin{abstract}
Os sacerdotes representavam um deus determinado, um templo determinado; não região, uma cidade. Os trabalhos públicos, os grandes empreendimentos não religiosos - como, principalmente, a construção de canais - eram atividades que afetavam regiões ligadas a vários templos. Por isso surgiram os dirigentes não vinculados aos templos, aqueles que mais tarde tornar-se-iam os reis (...) ele passa a atuar junto dela. Em troca, busca legitimação de seu poder. (PINSKY, 2018, p. 71)
\end{abstract}

No final do dia, o trabalhador, dependente desse sistema, deveria entregar o fruto de seu trabalho ao sacerdote, que muitas vezes o explorava. De tempos em tempos, os sumérios para manter seus deuses felizes, precisavam realizar sacrifícios ${ }^{76}$ de origem animal ou parte da colheita - para os deuses. A oferenda era levada ao templo e entregue aos sacerdotes, para que os mesmos, atuando como mediadores perante os deuses pudessem entregá-las. Esta mão de obra cada vez mais especializada começava a ser também utilizada na construção dos templos e das zigurates, que pouco a pouco ganhavam cada vez mais importância na religião dos sumérios.

\footnotetext{
76 Os sacrifícios tinham propósitos específicos, além de servirem de comida para os deuses também poderiam servir de purificação ou comunhão.
} 
ISSN 1982-8713

\section{Os Templos}

A arquitetura monumental dos templos era uma manifestação do papel central das instituições religiosas na sociedade suméria. A zigurate pode ser vista como reflexo dessa importância, ela era à base do templo, tendo o formato de uma pirâmide sem o topo. Eram geralmente feitas de tijolos de barro. Nos templos, o espaço de maior importância era a sala sagrada, onde se encontrava a estátua do deus senhorio. As salas de armazenagem, que ficavam ao redor do templo guardavam reservas de todo tipo, que poderiam ser usadas para escambo em benefício do templo. No período pós-dilúvio e pré-dinástico os sacerdotes acumulavam extremo poder, tanto que a gestão da vida religiosa e econômica passava pelo templo, que era proprietário dos terrenos cultiváveis e organizava as atividades políticas, representando o alicerce central em torno do qual gravitava toda a vida da cidade. Eles constituíam a unidade econômica da urbe, sendo, portanto, o centro do comércio terrestre, fluvial e marítimo (a base da riqueza suméria era a agricultura, o pastoreio e a pesca). Os templos foram construídos em formas exuberantes e imponentes para que pudessem ser um ponto estratégico visual e simbólico - pois representavam o coração do sistema teocrático/político - das cidades. A população local desenvolvia uma espécie de conexão com a divindade que ali residia, reconhecendo sua autoridade e proteção e estabelecendo assim, uma relação simbiótica.

Chamado de "é" em sumério, bitlbitûm em acádio, o templo era a morada dos dingir (deuses em sumério). Em seu interior encontrava-se a estátua da divindade, onde a preservação do artefato era imprescindível, devendo ser cuidado diariamente: roupas trocadas e limpas, comida sempre ofertada, hinos e cânticos de adoração. As oferendas eram fornecidas pelos crentes ou custeadas pelas próprias riquezas do templo. Cada cidade mesopotâmica podia ter um número de templos dedicados a diferentes deuses, mas um determinado deus era normalmente escolhido para receber um tratamento especial, considerado assim, patrono e protetor daquela cidade. Por exemplo, em Uruk, 
a cidade de cerca de 3.000 AEC, existiam dois templos maiores principais: um era dedicado a An, o deus supremo, o rei dos céus; o outro era dedicado a Inanna, a grande mãe, deusa da fertilidade, do amor e da guerra, não deixando assim, de existir, templos e santuários de deuses menores que também compartilhavam o espaço e o imaginário da cidade.

Anexos ao santuário encontravam-se os quartos dos sacerdotes ou sacerdotisas, que atuavam como servos da divindade: eles realizavam rituais junto ao altar, cantavam hinos de louvor e intercediam em nome da comunidade, podendo também, auxiliar individualidades que buscavam o socorro dos deuses. As divindades menores também tinham o seu santuário próprio, podendo ele estar localizado no interior dos templos maiores, ou também, situado em pequenos santuários erguidos entre as casas dos cidadãos. A arquitetura dos templos era uma manifestação do papel central das instituições religiosas na sociedade suméria. A adoração pública, quando ocorria, era realizada fora do templo, no grande pátio.

Figura 2 - Templo Branco dedicado a An, terceiro milênio AEC. Fonte: https://archaeologyillustrated.com/collections/uruk-southern-iraq-the-so-called-whitetemple-3000-bc/

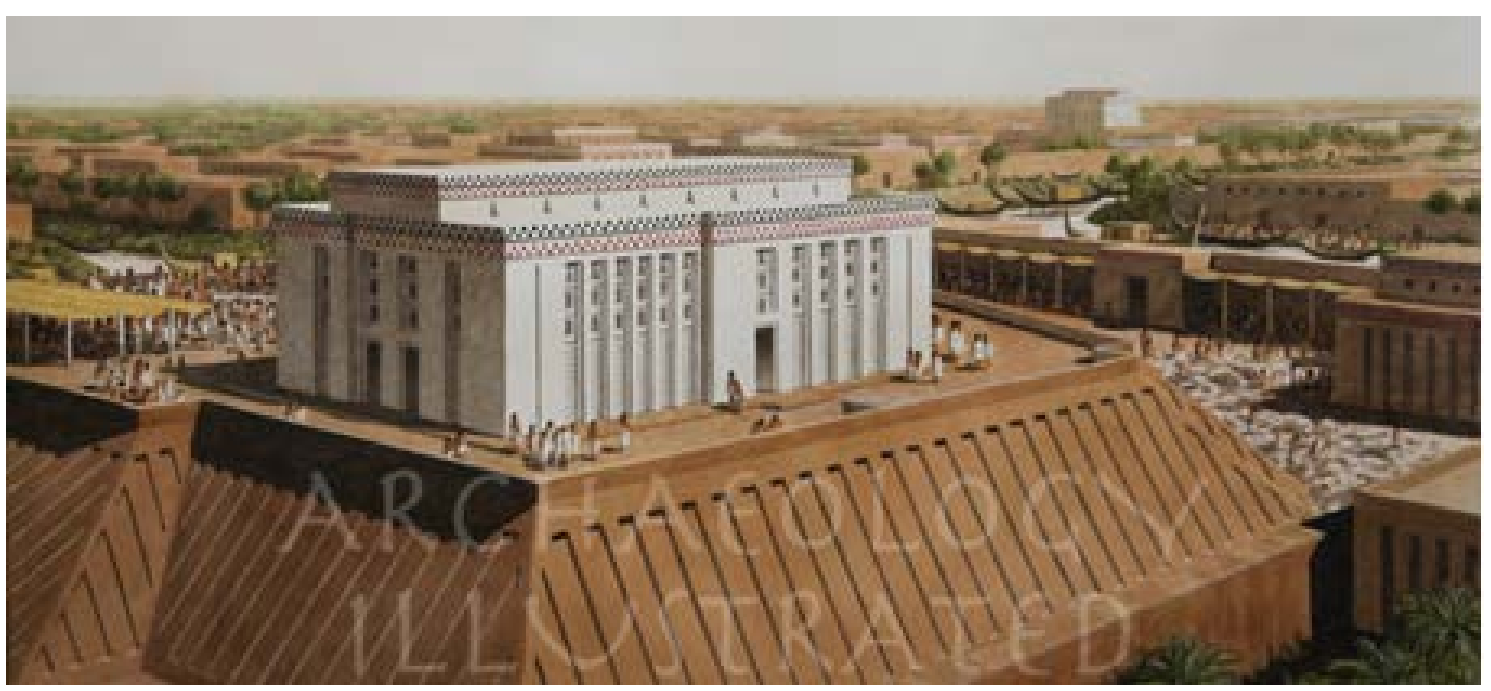


Figura 3 - Templo Eanna dedicado a Inanna, terceiro milênio AEC. Fonte:

$<$ https://archaeologyillustrated.com/collections/uruk-the-eanna-tempe-complex-where-thegoddess-inanna-reigned-supreme-around-3200-bc/

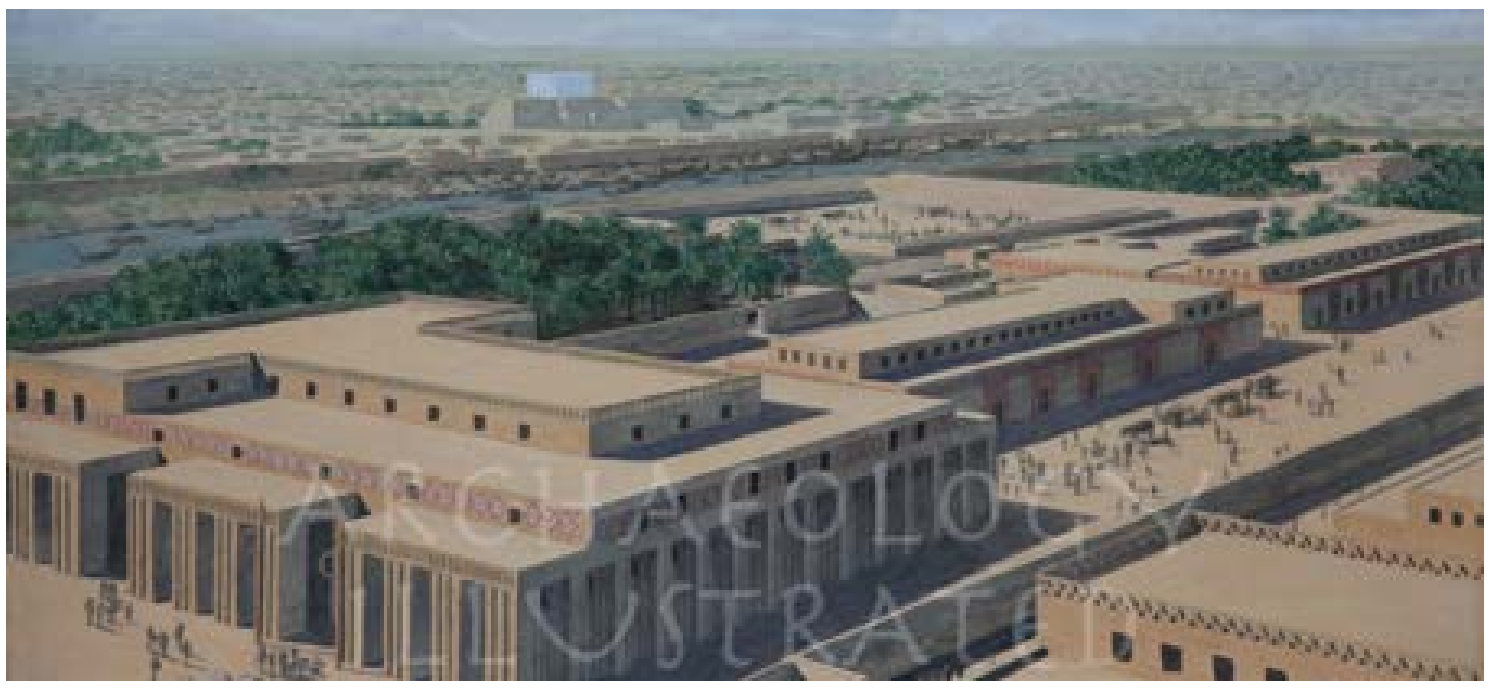

O senhor e titular do templo, chamado em ou en, acumulava as funções de chefe religioso e político - termo também usado, por exemplo, pelas divindades, como En-ki ou En-lil. Esse cargo manteve-se durante a dominação acádia, e posteriormente, na babilônia e assíria, porém com denominações próprias e níveis de influência distintos, respeitando a especificidade local e temporal. Logo abaixo, existia uma série de especialistas relacionados com as atividades do templo, por exemplo, aqueles que praticavam adivinhação através da leitura de entranhas. Os tupshanu eram os escribas, e também, os astrólogos. Aqueles que se comunicavam com as vontades divinas eram os shailu, os mediadores. Posteriormente, o título de lugal (rei) substituiu o de en. 0 lugal abre caminho para a monarquia sacra, pois era identificado como vigário da divindade, ou seja, o administrador do Estado cujos soberanos eram os deuses. Não confundindo com a ideia egípcia, onde o soberano tinha origem divina - na mesopotâmia, o rei possuía apenas a legitimação divina. No território das cidades, o rei apresentava-se como sacerdote e juiz supremo, devendo velar pela manutenção dos santuários e suas dependências. O lugal residia no palácio real, o outro polo da sociedade suméria. 


\title{
A Mitologia
}

A mitologia suméria diz respeito a fábulas diversas que, através de sua simbologia, buscavam explicar a origem das divindades, do homem e dos fenômenos da natureza que construíam seu imaginário e sua cultura. Enquanto que:

\begin{abstract}
O ciclo festivo e o calendário, o sistema ritual e cerimonial permitia o exercício de um controle sobre a realidade e sua renovação, subtraindo-a dos perigos do caos das origens. O mundo humano era assim conduzido dentro dos limites hierárquicos estabelecidos pelos deuses, que fundavam e legitimavam a existência humana, necessariamente obrigada a servir aos deuses e, consequentemente, ao rei (SCARPI, 2004, p. 44).
\end{abstract}

Abaixo, colocamos exemplos de duas narrativas. Uma diz respeito sobre o roubo dos "me" por Inanna, e a outra, relata o funcionamento das estações e da fertilidade do universo sumério.

Inanna queria aumentar o bem estar e a prosperidade de sua cidade, Uruk - mas também, queria a transformar no centro da suméria, para que seu nome fosse exaltado. Então, ela decidiu viajar até a cidade de Eridu, onde morava Enki - deus da sabedoria encarregado das leis fundamentais da civilização, os $m e^{77}$. Chegando ao $a b z u$, residência de Enki, jantaram e beberam juntos. Enki, embriagado, mostra mais de cem decretos divinos e os oferece como presente a Inanna. Ela os aceita e então retorna de imediato para Uruk. Enki ao retomar a sobriedade, percebe o erro que cometeu e envia diversas criaturas atrás de Inanna para resgatar os me, mas a deusa já havia chegado em segurança em seu lar. Uruk a partir de então, encara um grande período de crescimento e prosperidade.

\footnotetext{
77 Os me eram interpretados como um conjunto de regras e regulamentos, estabelecido para cada entidade e fenômeno cósmico, que permitia eternamente o funcionamento dos planos fixados pelas divindades criadoras. Embora os deuses possuam os me, eles não os criaram, são potências impessoais e eternas, que podem se concretizar nos seres, coisas, instituições ou sentimentos.
} 
ISSN 1982-8713

O mito, A descida ao submundo de Inanna, narra a busca da deusa pela expansão de seu poder e domínio, ao tentar reunir o mundo inferior, kur, à superfície. Desta maneira, inicia sua jornada rumo ao reino de sua irmã Ereshkigal a procura de seus segredos. Ao chegar perante as portas do mundo inferior deparou-se com a presença e ordem do guarda Neti que, somente autorizaria sua entrada, se, no decorrer dos sete portões ela retirasse seus artefatos, um a um. Existem versões que tratam estes artefatos como simples adornos e vestuário, enquanto outros relatos relacionam a nudez com a perda das sete insígnias de poder, que simbolizavam a entrega de seus poderes divinos. Inanna enfim chegou perante sua irmã, e acabou enfrentando toda a sua ira que, interpretou sua visita como uma ofensa, torturando-a e a transformando em um cadáver, içado por um gancho e deixado para secar. Sua ausência provocou uma crise cósmica que esterilizou o mundo.

Novamente os relatos são incompletos e aparecem em distintas versões sobre a narrativa, numa delas, Inanna, em posse dos me - outrora roubados - previu sua derrocada no submundo e traçou uma estratégia de retorno e ressurreição, que contava com o auxílio do próprio Enki. Já outra versão aponta para um julgamento realizado no submundo, onde sete juízes, sabendo da vital necessidade de retorno da deusa da fertilidade, traçaram um acordo: a deusa poderia ser substituída por outra pessoa para ocupar seu lugar no reino da morte. A escolha do substituto também encontra certa divergência, não em relação ao escolhido, que em ambos os casos é o mesmo, Dumuzi em sumério, Tammuz em hebraico, seu marido, deus da agricultura. A divergência ocorre, pois, em um relato, Dumuzi se ofereceu para ocupar o lugar da amada, outra versão conta que, quando regressou dos mortos, acompanhada por gallas - demônios Inanna o encontrou sentado em seu trono no comando de seu reino, e que, tomada por uma ira, condenou-o a assumir seu lugar no kur, sendo levado assim, pelos gallas. Relatos apontam para a piedade de Ereshkigal que permitiu que Dumuzi revezasse com sua irmã Geshtinanna a penitência, dessa forma, passaria seis meses no kur e seis meses na terra, fenômeno que está muito associado aos ciclos das estações e da fertilidade da 
terra. Já outro apontamento traz Geshtinanna intervindo perante Inanna e, conseguindo assim, o revezamento com seu irmão na punição.

\section{A Cosmogonia}

Primeiramente, havia Nammu - o mar primordial - como nada é dito quanto a sua origem, é provável que os sumérios a concebiam como eterna e não criada. Nammu gerou $A n$ - o céu - e $K i$ - a terra - originalmente unidos. Dessa relação do céu e da terra proveio o ar, chamado de Enlil que, encontrando-se sozinho naquele cosmo escuro que para os sumérios era feito de lápis-lazúli escuro - criou Nanna - deus da lua - para iluminar tal universo. Nanna concebeu Utu - o sol - que se tornou mais reluzente que seu pai. Enlil separou o pai/céu An da mãe/terra $K i$ - narrado no mito Enlil e a Criação do Pickax -, nesse momento, Nammu forjou Enki (deus das águas doces e da sabedoria) utilizando-se das lágrimas de An quando, o mesmo, foi separado de Ki. A união de Enlil com a sua mãe Ki (identificada como Ninmah, grande rainha; Ninhursag, rainha da montanha; Nintu, rainha que dá a luz) criou a organização do universo. Ambos, com a ajuda de Enki, conceberam a fauna e a flora. Enquanto que, a humanidade foi criada por Nammu, Enki e Ninmah. Enlil e Enki mandaram Labar - deus do gado - e Ashnan - deusa dos grãos - para tornar a terra próspera e abundante. É importante perceber neste momento que existiam deuses antes da separação do céu e da terra.

A base da cosmogonia suméria era a água primordial, Nammu, a mãe de todos. As águas salgadas de Nammu preenchiam todo o cosmo, onde An-ki conseguia manterse fixo e estável. An-ki (céu-terra) é a expressão suméria que quer dizer universo. A terra, Ki, era um disco plano onde estava repousada uma abóboda - Kramer (1963, p.112) diz que, os sumérios imaginavam-na feita de latão e, era azul porque refletia o azul das águas. An ficava nas bordas da terra. Abaixo de Ki, estava o Abzu - morada de Enkiconhecido como as águas do abismo, dele provinham às águas para os rios Tigre e Eufrates, e para as outras fontes de água doce. Inferior a este, encontrava-se o kur - o inframundo. Ki então era composta pela terra, pelo abzu e pelo kur; enquanto An era 
formado pelo céu e o espaço acima deste, tido como o céu cósmico. Entre An-ki, está Enlil - a atmosfera, o ar. Em seus domínios estão também o sol (Utu), a lua (Nanna), os planetas e as estrelas - todos compostos do mesmo material que a atmosfera, porém, com a adição de luminosidade. Seguindo a criação dos corpos astrais, as plantas, os animais e a vida humana foram criados.

Efetuando, conduzindo e verificando este universo, estava um panteão diversificado que controlava o cosmos e ditavam suas leis. Cada qual possuía seus domínios relacionados com questões do cotidiano sumério e com a natureza. Para este povo sem a supervisão dos deuses, as cidades, as terras, os campos tudo desmoronaria, pois foram presentes dados pelos deuses. O cosmos voltaria para o caos. Os sumérios concebiam seus deuses em forma antropomórfica, fortalecendo assim sua proximidade com os mesmos. Os deuses atuavam no cotidiano da sociedade, e atividades simples, como acender uma fogueira ou curar um doente estavam imersas em magia. Os sumérios acreditavam que a vontade dos deuses era manifestada na natureza e que, com uma habilidade própria, a mesma poderia ser lida e interpretada, dando ao ser humano uma luz em relação à intenção divina. Sacerdotes especialistas eram os encarregados da responsabilidade de adivinhar o desejo do céu inspecionando órgãos (especialmente o fígado) de animais sacrificados ou estudando os corpos celestiais com suas mudanças e movimentos.

Antes de criarem a humanidade, os deuses exerciam funções similares ao cotidiano dos sumérios, eles pescavam, lavravam a terra, construíam canais de irrigação para abastecerem as plantações etc. Um dia, os deuses ficaram cansados de todo esse trabalho pesado, e reclamaram para a mãe de todos, Nammu, que encarregou Enki para resolver à problemática. Com o auxilio das oito deusas parteiras Enki fecunda Ninmah, com a argila criadora que existia no $a b z u$, fazendo-a conceber a humanidade, aliviando assim, o trabalho dos deuses. E deste momento em diante, estes servos humanos deveriam trabalhar na terra e cultivar alimentos substituindo os deuses no trabalho pesado. Após vagarosos anos de servidão e obediência, o crescimento demográfico 
ISSN 1982-8713

humano favoreceu uma reação dos subjugados, o que gerou uma grande rebelião contra seus criadores. Os criados levantaram suas vozes contra Enlil e recusaram-se continuar a trabalhar. Foram três revoltas reprimidas pelos deuses, com epidemias, estiagem e pobreza, até que, no quarto levantamento, Enlil decide exterminar todos os humanos através de um grande dilúvio, Enki, no entanto, interveio e conseguiu salvar apenas um individuo: Ziusudra, que teria sido encarregado por Enki de abandonar suas posses para construir um grande navio, o "preservador da vida", similar ao mito da arca de Noé.

\section{Considerações Finais}

Ao analisar os contextos das civilizações antigas do Oriente Próximo, em especial o que ocorria ao sul da Mesopotâmia, observa-se um cenário de extrema diversidade cultural e um dinâmico e plural sincretismo religioso. Pensar a antiguidade suméria é entender o processo civilizacional da história da humanidade e suas constantes mutações. Assim como o homem se reinventa, ele também reinventa as formas de estruturação e organização. A jornada por uma compreensão da realidade diversa e heterogênea passa pelo entendimento e conhecimento desse contexto mesopotâmico multifacetado. Apreender e compreender os períodos imemoriáveis da nossa história e como se desenvolveram as culturas que hoje conhecemos, floresce e exercita nossas práticas e costumes atuais. Aprofundando o conhecimento sobre a pluralidade e intensidade dos povos antigos, expande-se o movimento da consciência, proporcionando ao homem se redescobrir, se revisitar como indivíduo instaurador desse mundo e de sua própria experiência. Presenciando sua história, reconhecendo a natureza diversificada humana e suas profundas relações com a alteridade, o indivíduo assume um estado virginal portador de uma nudez existencial, pronto para reconhecerse de forma plena passando a atuar no mundo imerso no respeito pela diferença. 


\section{Referências Bibliográficas}

ALEXANDER, Pat (Org.). As Religiões do Mundo: Do primitivismo ao século XX. São Paulo: Companhia Melhoramentos, 1996.

BEAULIEU, Paul-Alain. Mesopotamia. In: JOHNSTON, Sarah. Ancient Religions. Cambridge: The Belknap Press of Havard University Press, 2007.

GAARDER, Jostein; Hellern, Victor; Notaker, Henry. O Livro das Religiões. São Paulo: Companhia das Letras, 2000.

GARELLI, Paul. O Oriente Próximo Asiático: das origens às invasões dos povos do mar. São Paulo: Pioneira: Ed. Da Universidade de São Paulo, 1982.

JACOBSEN, Thorkild. Mesopotamian Religion. Disponível em: <https://www.britannica.com/topic/Mesopotamian-religion >. Acesso em: 06 mar 2019.

KRAMER, Samuel. The Sumerians: Their history, culture and character. Chicago: The University of Chicago Press, 1963.

KRAMER, Samuel. Sumerian Mythology: A Study of Spritual and Literary Achievement in the Third Millennium B.C. Forgotten Books, 2010

KRIWACZEK, Paul. Babilônia: a Mesopotâmia e o nascimento da civilização. Rio de Janeiro: Zahar, 2018.

LERNER, Gerda. The Creation of Patriarchy. New York: Oxford University Press, 1987.

LÉVÊQUE, Pierre. As Primeiras Civilizações: da Idade da Pedra aos Povos Semitas. São Paulo: Lugar na história, 2009.

PINSKY, Jaime. As Primeiras Civilizações: História natural, história social. Agricultores e criadores. Mesopotâmicos, egípcios e hebreus. 25. ed., $5^{a}$ reimpressão. São Paulo: Contexto, 2018.

ROSSI, Alexandre. Sumérios. In: FUNARI, Pedro (Org.). As Religiões que o Mundo Esqueceu: Como egípcios, gregos, celtas, astecas e outros povos cultuavam seus deuses. São Paulo: Contexto, 2009, p. 18-26.

\section{Imagens}

Figura 1: Coleção Online do British Museum, Queen of th Night, aproximadamente décimo nono, décimo oitavo século AEC na Babilônia (Asia, Iraque, Sul do Iraque). Disponível $<$ https://research.britishmuseum.org/research/collection online/collection object de tails.aspx?objectld=1355376\&partld=1>. Acesso em: janeiro de 2020. 
NEARCD: Revista Eletrônica de Antiguidade 2020, Volume XII, Número I - ISSN 19882-8713

Núcleo de Estudas da Antiguidade -NEA

Universidade do Estada do Rio de Janeiro

ISSN 1982-8713

Figura 2: Templo Branco dedicado a An, terceiro milênio AEC. Disponível em: $<$ https://archaeologyillustrated.com/collections/uruk-southern-iraq-the-so-calledwhite-temple-3000-bc/>. Acesso em: janeiro de 2020.

Figura 3: Templo Eanna dedicado a Inanna, terceiro milênio AEC. Disponível em: $<$ https://archaeologyillustrated.com/collections/uruk-the-eanna-tempe-complexwhere-the-goddess-inanna-reigned-supreme-around-3200-bc/>. Acesso em: janeiro de 2020. 